\title{
Cordons Sanitaires and the Rationalisation Process in Southern Europe (Nineteenth-Century Majorca)
}

\author{
PERE SALAS-VIVES ${ }^{1}$ and JOANA-MARIA PUJADAS-MORA ${ }^{2 *}$ \\ ${ }^{1}$ History Department, University of the Balearic Islands, Cra. de Valldemossa, km 7.5, \\ Palma (Balearic Islands), 07122, Spain \\ ${ }^{2}$ Centre for Demographic Studies: Autonomous University of Barcelona, Ca n'Altayó, Building E2, \\ Campus UAB, Bellaterra (Barcelona), 08193, Spain
}

\begin{abstract}
Never before the nineteenth century had Europeans, especially in the south, adopted cordons sanitaires in such great numbers or at such a fast rate. This article aims to analyse the process of the rationalisation and militarisation of the cordons sanitaires imposed in the fight against epidemics during the nineteenth century on the Mediterranean island of Majorca (Spain). These cordons should be understood as a declaration of war by the authorities on emerging epidemics. Epidemics could generate sudden and intolerably high rises in mortality that the new liberal citizenship found unacceptable. Toleration of this type of measure was the result of a general consensus, with hardly any opposition, which not only obtained the support of scientists (especially in the field of medicine) but also of most of the local and provincial political elite, and even of the population at large.
\end{abstract}

Keywords: Cordons sanitaires, Epidemics, Liberal State, Rationalisation, Militarisation

Cordons sanitaires, understood as extreme and exceptional forms of isolation by land and sea in the threat of an epidemic, were not an invention of nineteenth-century sanitary, or health, modernisation but were part of the general programme of social and political change that it entailed. ${ }^{1}$ Never before had this type of measure been adopted in such great

* Email address for correspondence: jpujades@ced.uab.es

We would like to thank Dr Isabel Moll for her help in writing this article and Mr Michael Pietroni FRCS for the linguistic review.

\footnotetext{
${ }^{1}$ Following Teresa Carnero introduction in T. Carnero (ed.), Modernización, desarrollo político y cambio social [Modernisation, political development and social change] (Madrid: Alianza, 1992), 9-34, we understand modernisation as a process of social change, in which transformations in the productive sphere and in the social structure within which they take place in the field of politics and government combine, even if there are no actual connections between them all. Therefore, the process refers both to the development of capitalism and to the new liberal state, with a great infrastructural capacity to intervene in society, see Michael Mann, The Sources of Social Power, 2: The Rise of Classes and Nation-States, 1760-1914 (Cambridge: Cambridge University Press, 1993).
} 
numbers or at such a fast rate in southern Europe. ${ }^{2}$ These actions may have been triggered by a complex set of circumstances.

Among these, it is worth noting that there was a perceived rise in the risk of epidemics associated with increases in international commercial traffic between European regions, from tropical areas and, in general, from east to west. Furthermore, southern Europeans were anxious about their proximity to areas considered much less salubrious, such as North Africa and the Islamic countries in the eastern Mediterranean. ${ }^{3}$ For this reason, cordons sanitaires as preventive measures were more commonly used by nineteenthcentury Mediterranean nations and colonies, for example, Naples, Sardinia, Venice, Spain, Malta, Cyprus, Egypt and Gibraltar, than by nations in the Atlantic regions. ${ }^{4}$ This spread of the use of cordons could be also explained by the fact that, due to the importance of trade for Mediterranean areas, countries in southern Europe preferred bearing the costs of a temporary closure of commercial activity to carrying out the more costly

2 See Esteban Rodríguez Ocaña, 'El resguardo de la salud: Organización sanitaria española en el siglo XVIII' [Safeguarding health: Spanish health organisation in the 18th century], Dynamis, 7-8 (1987-88), 145-70; Joaquim Bonastra Tolós, 'Innovaciones y continuismo en las concepciones sobre el contagio y las cuarentenas en la España del siglo XIX: Reflexiones acerca de un problema sanitario, económico y social' [Innovations and continuity in conceptions regarding contagion and quarantines in 19th-century Spain: reflections on a health, economic and social issue], Scripta Nova: Revista de Geografía y Ciencias Sociales, 69 (2000), http://www.ub. es/geocrit/nova-ig.htm; or Eugenia Tognotti, 'Lessons from the History of Quarantine, from Plague to Influenza A', Emerging Infectious Diseases, 19, 2 (2013), 254-9. All these authors not only highlight the continuities, but also the innovations put into practice during the 19th century.

${ }^{3}$ We are, of course, following the theses of Peter Baldwin, Contagion and the State in Europe 1830-1930 (Cambridge: Cambridge University Press, 1999) regarding this point.

${ }^{4}$ See, for Naples, Frank M. Snowden, Naples in the Time of Cholera 1884-1911 (Cambridge: Cambridge University Press, 1995); for Sardinia Norma Howard-Jones, The Scientific Background of the International Sanitary Conferences 1851-1938 (Geneva: World Health Organization, 1975). For Venice, see Eugenia Tognotti, op. cit. (note 2), 254-9 and Eugenia Tognotti, 'The Origins of the Health Defence System against Contagious Illness: The Strategies of Isolation and Quarantine in Mediterranean Cities from the XIV-XIX Centuries', Alder Museum Bulletin, 31, 1 (2005), 6-17. For Spain, it is interesting to highlight the example of the cities of Alacant (Alicante) or Barcelona, both Mediterranean cities, owing to their concurrent use of cordons sanitaires with Majorca, at the beginning of the 19th century. See Salvador Salort Vives, 'Town planning, economy and health: Alacant's harbour, from a death lake into a modern harbour (1900-14)', Boletín de la Asociación de Geógrafos Españoles, 45 (2007), 423-25 ,or Mercedes Pascual Artiaga 'La ciudad ante el contagio: medidas políticas y administrativas dictadas en la epidemia de fiebre amarilla de 1804 en Alicante' [The city facing the contagion: political and administrative measures adopted in the yellow fever epidemic of 1804 in Alicante], Asclepio, 54, 1 (2002), 125-54 and Francesc Bonamusa and Joan Serrallonga, Del roig al groc: Barcelona, 1868-71: Quintes i epidèmies (Barcelona: L'Avenç, 1995) [From red to yellow: Barcelona, 1868-71: epidemics and conscripts] or Joan Serrallonga Urquidi, 'Epidemias e historia social: Apuntes sobre el cólera en España, 1833-65' [Epidemics and social history: notes on cholera in Spain, 1833-65], Historia Social, 1996, 24, 7-21. However, the use of this quarantine measure was to be found round the whole coast of Spain, as the seminal works on the study of cholera across 19th-century Spain report. See Jose Maria Lopez Piñero, Luis Garcia Ballester and Pilar Faus Sevilla, Medicina y sociedad en la España del siglo XIX [Medicine and society in 19th-century Spain] (Madrid: Estudios y Publicaciones, 1964), or Juan J. Fernández Sanz: El año de la vacunación de Ferran: Trasfondo político, médico, sociodemográfico y económica de una epidemia [The year of the vaccination of Ferrán: political, medical, sociodemographic and economic backdrop of an epidemic] (Madrid, Fundación Ramón Areces, 1990). For Portugal, see Maria Antónia Pires de Almeida, 'Fighting disease and epidemics: Ricardo Jorge and the internationalization of Portuguese science', Vesalius: acta internationales historiae medicinae, 19, 1 (2013), 19-23. For Malta, Cyprus and Gibraltar, see Baldwin, op. cit. (note 3), and for Egypt, Paul Slack, Plague: A Very Short Introduction (Oxford University Press, Oxford, 2012). It is worth mentioning that the introduction of cordons sanitaires in Egypt was part of Muhammad Ali's modernisation reforms, a purpose completely different from the above-mentioned use of cordons as palliative measures in fighting against epidemics in regions where important health reforms had not yet been introduced, as some sources in the bibliography state. 
fundamentalpublic reforms that they needed. ${ }^{5}$ This system would be completely different ${ }^{6}$ from the one applied, for instance, in England ${ }^{7}$ due to the geoepidemiology of disease, which refers, in terms of geography, to the proximity to areas where cholera or other contagious diseases originated. ${ }^{8}$ Nevertheless, the use of cordons sanitaires in southern Europe declined as scientific evidence based on microbiological analysis advanced.

Moreover, citizens considered cordons sanitaires reliable measures for avoiding epidemics due to their past success in combating plague and because of the persistence of contagionism as a medical theory endorsing their adoption. ${ }^{9}$ The First International Sanitary Conference (1851) might have reinforced this idea when, among other statements, it concluded that quarantines set up on islands or peninsulas could be more effective against epidemics than those set up inland on the continent, because they were welldelimited spaces. ${ }^{10}$ Besides, a new epidemic cycle had appeared from the beginning of the nineteenth century with yellow fever and cholera, and plague had re-appeared. Lastly, it could be argued that in general, the new nation-states were much more capable and interested - in the mobilisation of material and human resources than the previous absolutist states. This was due to greater and more intensive infrastructural power and, of course, to the institutionalisation of citizenship. ${ }^{11}$

Thus, in the words of Michael Mann ${ }^{12}$, we were witnessing the birth of a mixed state, capable of intervening in the civilian sphere, especially from the second half of the nineteenth century onwards. Although town councils were institutions in charge of health issues, this authority was legally delegated by the central government. ${ }^{13}$ Even the

5 On this statement, see Esteban Rodríguez Ocaña, 'La salud publica en España en el contexto europeo, 18901925' [Public health in Spain in the European context, 1890-1925], Revista de Sanidad e Higiene Pública, 68 (1994), 11-27; Snowden, op. cit. (note 4) and Baldwin, op. cit. (note 3).

${ }^{6}$ On this topic, see Alexander Chase-Levenson, 'Early nineteenth-century Mediterranean quarantine as a European system', in Alison Bashford (ed.), Quarantine: Local \& Global Histories (Basingstoke: Palgrave Macmillan, 2016), 35-53.

${ }^{7}$ Krista Maglen, 'The first line of defence. . ', The English System: Quarantine, Immigration and the Making of a Port Sanitary Zone (Manchester: Manchester University Press, 2014), 21-59.

${ }^{8}$ Baldwin, op. cit. (note 3), 211-12.

9 As demonstrated in the discussions at the International Sanitary Conferences, as can be seen in Mark Harrison, 'Disease, Diplomacy and International Commerce: The Origins of International Sanitary Regulation in the Nineteenth Century', Journal of Global History, 1 (2006), 197-217, and Valeska Huber, 'The Unification of the Globe by Disease? The International Sanitary Conferences on Cholera, 1851-1894', The Historical Journal, 49, 2 (2006), 453-76. Meanwhile, Eugenia Tognotti, op. cit. (note 2), 254-9 defends the idea that the local authorities were reluctant to abandon the quarantine systems and cordons sanitaires, even in areas where their efficacy was most doubtful, because of the false sense of safety they inspired in the population.

${ }^{10}$ Baldwin, op. cit. (note 3).

${ }^{11}$ Patrice Bourdelais, Les Épidémies terrassées: Une histoire des pays riches [Defeated epidemics: a tale of rich countries] (Paris: La Martinière, 2003) maintains that it was precisely the state's ever-stronger intervention in favour of health which explains the substantial improvements in health between 1859 and 1940, a period in which improvements went from being a government imposition to being demanded by citizens. Also see: Charles Tilly, Coercion, Capital and European States AD 990-1992 (Cambridge, MA: Blackwell, 1990); Claude Lefort, 'Les Droits de l'homme et l'État-Providence' [Human rights and the welfare state], Esprit, 108, 11 (1985), 65-79, or Patrick Zylberman, Tempêtes microbiennes: Essai sur la politique de sécurité sanitaire dans le monde transatlantique [Microbial turmoils: essay on health and safety policies in the transatlantic world] (Paris: Gallimard, 2013).

12 Mann, op. cit. (note 1). See also Lutz Raphael, Ley y orden: Dominación mediante la administración en el siglo XIX [Law and order: dominance through the administration in the 19th century] (Madrid: Siglo XXI, 2008).

13 Joaquín del Moral Ruíz, 'Las funciones del Estado y la articulación del territorio nacional: símbolos, administración pública y servicios' [The functions of the state and the articulation of national territory: symbols, public administration and services], in J.d. Moral Ruíz, J. Pro Ruiz and F. Suárez Bilbao (eds.), Estado y territorio en España, 1820-1930: La formación del paisaje nacional [State and territory in Spain, 1820-1930: the formation of the national landscape] (Madrid: Catarata, 2007), 17-358. 
regular army, which was the result of the new nation state, took on civilian functions that were different from its traditional, exclusively military, roles. In this way, their capacity to respond to health disasters increased, despite their limitations, especially in the case of Spain, and the limitations of medical science at the time. ${ }^{14}$ The centralisation of health care was just one of the corollaries, which in Spain was established by the General Health Law of $1855,{ }^{15}$ although it certainly had important precedents. Hence, Spain's policy for epidemic prevention evolved from focusing on the single aim of isolation to a much more complex prophylactic policy. To these quarantine measures were added other preventive actions, such as urban hygiene.

The onset of this change appeared upon the death of Ferdinand VII of Spain $(1833)^{16}$ and was largely sanctioned by the General Health Law of $1855 .{ }^{17}$ In no cases were cordons sanitaires forbidden but, rather, an attempt was made to regulate their use and abuse, and they were placed under central government control and removed from the control of provincial or local governments. ${ }^{18}$

This study aims to show, through an analysis of the case of the island of Majorca, the generalisation and prevalence of cordons sanitaires and how they contributed to the fight against epidemics in the nineteenth century. The scientific postulates at the time were derived from contagionist theory but, by the end of the period, they were adapted to the bacteriological approach. ${ }^{19}$ Moreover, the new liberal governments overcame the dichotomy between freedom and coercion in favour of the latter, continuing to perform the classic duties of absolute states, while preserving the rights of citizenship, and adding new duties such as the preservation of life and the provision of a healthy environment. ${ }^{20}$

\footnotetext{
${ }^{14}$ For Eric L. Jones, Crecimiento recurrente: El cambio económico en la historia mundial [Recurring growth: economic change in world history] (Madrid: Alianza, 1997), 218: the most important factor was an increase in the number of bureaucrats who could devote themselves to rationalising the struggle against disasters, including epidemics, thus reducing their effects.

${ }^{15}$ However, note that enforcement of the law was left in the hands of the delegations and councils, a situation similar to what is described by Abram de Swaan, In the Care of the State: Health Care, Education and Welfare in Europe and the USA in the Modern Era (Cambridge: Polity Press, 1988) in the case of Great Britain.

${ }^{16}$ Carles Grabuleda Teixidor, 'Salut pública i creixement urbà: Política i acció social en el sorgiment de la Barcelona Contemporània' [Public health and urban growth: politics and social action in the rise of Contemporary Barcelona] (unpublished PhD thesis: Pompeu Fabra University, 2002); Esteban Rodríguez Ocaña and Ferrán Martínez Navarro, Salud pública en España: de la Edad Media al siglo XXI [Public health in Spain from medieval times to the 21st century] (Granada: Escuela Andaluza de Salud Pública, 2008). Likewise, the Royal Orders of 24 August 1834 and 31 August 1854 quoted by Joana Maria Pujadas-Mora, 'Les epidèmies "invisibles" i "visibles" de còlera a la Ciutat de Palma: gestió municipal, Segle XIX' [The 'invisible' and 'visible' epidemics of cholera in the city of Palma: municipal management in the19th century] (unpublished $\mathrm{PhD}$ thesis: University of the Balearic Islands, 2005).

${ }^{17}$ It must be noted that this law does not stand against isolation measures in themselves but rather against the perversion of the system, especially in the use of land cordons (Juan José Fernández Sanz, El año de la vacunación de Ferrán: Trasfondo político, médico, sociodemográfico y económico de una epidemia (Madrid: Fundación Ramón Aceres, 1990)).

18 Pujadas Mora, op. cit. (note 16), and Joana Maria Pujadas-Mora, 'La gestión municipal de las epidemias de cólera en Palma (Mallorca) durante el siglo XIX: "Epidemias invisibles", [Municipal management of cholera epidemics in Palma (Majorca) during the 19th century: "Invisible epidemics"], in J.M. Beascoechea Gangoiti, M. González Portilla and P.A. Novo López (eds.), La ciudad contemporánea, espacio y sociedad [The contemporary city, space and society] (Bilbao-Puebla: University of Pais Vasco - Autonomous University of Puebla, 2006), 291-310.

${ }^{19}$ Especially as regards the identification of a causal agent for each illness, thus making the microbe the new enemy and not so much the ill person, Josep Lluís Barona Vilar, Salud, enfermedad y muerte [Health, illness and death] (Valencia: Diputació de València: Institució Alfons el Magnànim, 2002).

${ }^{20}$ Mann, op. cit. (note 1), 627-35.
} 
Our starting hypothesis is that the use of cordons sanitaires was not contrary to the main economic interests of the island, nor was it the subject of ideological debate, except for their use inland. ${ }^{21}$ On the contrary, they contained an essential element for the development of commercial capitalism, which, parallel with political liberalism, was growing stronger and stronger in this area of the western Mediterranean. ${ }^{22}$ Lastly, and in relation to these assumptions, it can be observed how, as the century progresses, the cordons were adapted and organised in line with the process of political, administrative and economic modernisation. Specifically, a coercive measure such as this must have the support of the army. For this reason, we believe that the use of cordons sanitaires and quarantines without a progressive militarisation of society would be inconceivable. They required either a permanent army that presupposed compulsory military service or security and surveillance forces such as the Carabineros [paramilitary gendarmerie] (since 1829), the Guardia Civil [Spanish military police] (created in 1844) or the local police in Palma since $1852 .^{23}$

The sources we used were basically local and regional. As there are no documentary series covering the whole period under study, nor centralised documentation on this issue, we set up a database by compiling information from various archives. From the municipal field, we analysed the series entitled Health-orders, which includes orders from the higher echelons of power to the mayors of Majorcan towns, from 1784 to 1870 . Also in the towns, health news items appearing in municipal records - a type of documentation that presents a constant series throughout the whole century and consultation of which is very time-consuming - were also consulted. Lastly, the information kept since 1854 in the Archive of the Consell de Mallorca, successor to the former provincial delegation, was of great interest. ${ }^{24}$ This institution was in charge of organising the cordons sanitaires, even though these cordons required the co-operation of the town councils ${ }^{25}$ and the approval

\footnotetext{
${ }^{21}$ We do not assume, therefore, a direct relationship between liberalism and anti-contagionism, or between contagionist measures and commercial interests, along the lines pointed out by Baldwin, Contagion and the State, in contrast to the claims of Erwin H. Ackerknecht, 'Anticontagionism between 1821 and 1867', Bulletin of the History of Medicine, 22 (1948), 532-93. On this topic, see also Christopher Hamlin, 'Commentary: Ackerknecht and 'Anticontagionism': A Tale of Two Dichotomies', International Journal of Epidemiology, 38 (2009), 22-7.

22 Our study is based on the belief that the state resulting from the liberal revolution in Spain did have the ability to promote social and economic modernisation. Therefore, our thesis promotes the idea that, within the European context, Spain was unusual, as pointed out by Fernando Molina Aparicio and Miguel Cabo Villaverde, 'Historiografia i nacionalització a Espanya: Reflexions finals' [Historiography and nationalisation in Spain: final reflections], Segle XX: Revista catalana d'història, 4 (2011), 161-9 and Salvador Calatayud, Jesús Millan and Maria Cruz Romeo, 'El Estado en la configuración de la España contemporánea: Una revisión de los problemas historiográficos' [The state in the configuration of contemporary Spain: a review of historiographic problems], in S. Calatayud, J. Millan and M. Cruz Romeo (eds,) Estado y periferias en la España del siglo XX: Nuevos enfoques [State and peripheries in 20th-century Spain: new approaches] (Valencia: University of Valencia, 2009), 9-130. Regarding capitalist development on Majorca and its integration into economic globalisation, our ideas are based on the contributions of Carles Manera Erbina, Història del creixement econòmic a Mallorca (1700 2000) [History of economic growth on Majorca (1700-2000)] (Palma de Mallorca: Muntaner, 2001), and Ramon Molina de Dios, Treball intensiu, treballadors polivalents (Treball, salaris i cost de vida) [Work, salaries and cost of living], (Mallorca, 1860-1936) (Palma de Mallorca Conselleria d'Economia, Comerç i Indústria, 2003).

${ }^{23}$ Among other studies see, in the case of Spain, Fernado Puell de la Villa, Historia del ejército en España [History of the Spanish army] (Madrid: Alianza, 2000) and, for a general view, Charles Tilly, Coercion, Capital, and European States: AD 990-1990 (Cambridge: Blackwell, 1990).

24 The provincial delegation was an elective institution, presided over by the governor until 1870, dating back to the Constitution of 1812. Its functions were exercised over the whole provincial territory - in this case the Balearic Islands. It had an administrative, collaborative and supervisory nature.

${ }^{25}$ In fact, as was common in Europe at that time, practical administration and the application of a large body of the legal corpus depended on municipal administration and on its revenue offices. In the case of Spain, see Pedro Carasa Soto (ed.), Ayuntamiento, Estado y Sociedad: Los poderes municipales en la España contemporánea
} 
and participation of the army and, of course, the ministry of the interior [Gobernación in Spanish]. ${ }^{26}$ Because of this, it is possible to transcend the scattered and fragmented documentation referring to this issue, and the perspectives of different administrations, and occasionally opposing interests can, in turn, be compared. In addition, news items appearing in official gazettes or in the press of the time were extremely useful.

\section{Rationalisation and Militarisation of the Cordons Sanitaires}

On the island of Majorca between 1787 and 1899 a total of twenty-eight defensive rings were set up in order to guard the whole of the island perimeter intensively from the land, with the support of coastguard boats. This meant an average of one cordon every four years, with greater intensity in the first half of the century. Simultaneously, ordinary protection systems and health surveillance were increased and rationalised at ports. This preventive policy was due to three epidemic threats: the plague, yellow fever and cholera. The first two took place before 1833, the date of the first wave of cholera in Spain. Cholera became the prevalent disease from then on, albeit not exclusively. ${ }^{27}$

The sea-land cordons depended on the political chief or civil governor, who in turn was the central government delegate, specifically from the ministry of the interior from 1834 onwards. Meanwhile, the provincial boards of health had broader functions, but with limited administrative capacity; and were also presided over by the civil governor, whose authority over health intervention was enhanced after the General Health Law of $1855 .{ }^{28}$ In the second half of the century, the provincial institutions ${ }^{29}$ were more resolutely in favour of cordons sanitaires than was the central government. The town councils were also in favour, despite their reticence when it came to defraying their costs; so much so, that until 1834 they conducted their own quarantines with the blessing of the higher authorities. From this date onwards they did not hesitate to break the law when they believed it necessary to set up local cordons, as we shall see below. However, the establishment of cordons sanitaires was unthinkable without the consent and collaboration of the army, which normally acted following the recommendations of, firstly, the provincial board of

[Council, state and society: municipal powers in contemporary Spain] (Valladolid: Fundación Municipal de Cultura - Instituto de Historia 'Simancas', 2000); and Joaquín del Moral Ruíz, 'Las funciones del Estado y la articulación del territorio nacional: símbolos, administración pública y servicios', in J.d. Moral Ruíz, J. Pro Ruiz and F. Suárez Bilbao (eds.), Estado y territorio en España, 1820-1930. La formación del paisaje nacional (Madrid: Los libros de la Catarata, 2007), 17-358. Meanwhile, Swaan, op. cit. (note 12); Mann, op. cit. (note 1); and Raphael, op. cit. (note 12) highlight the great importance of town councils in the development of public administration in western Europe during the second half of the 19th century, although in all cases they act as delegates of the central state.

${ }^{26}$ Serrallonga Urquidi, op. cit. had already pointed out the fact that in Italy and Spain all health policies depended ultimately on the ministry of the interior, also in charge of internal security and with a clear centralising purpose. ${ }^{27}$ Pere Salas Vives, 'Cordons sanitaris (Majorca, 1787-1899)' [Cordons sanitaires (Majorca, 1787-1899)], Gimbernat, 37 (2002), 55-82 and Pere Salas Vives, 'Libertad y/o derecho a la vida. El resguardo sanitario durante el primer liberalismo (Mallorca, siglo XIX)' [Freedom and/or right to life: health protection during the first liberalism (Mallorca, siglo XIX)], Historia Social, 68 (2010), 69-85.

28 Vilar, op. cit. (note 19).

29 These institutions also belonged to the civil government, the provincial delegation, the provincial council until 1868 and the provincial commission from 1870 (Arturo Cajal Valero, El Gobernador Civil y el Estado centralizado del siglo XIX [The civil governor and the centralising state in the 19th century] (Madrid: Ministerio de Administraciones Públicas, 1999)). 
health and, then, the provincial commission. What is more, as time went by, this bond increased significantly.

The treatment of space is the first aspect in the militarisation of the cordons. Majorca was considered as a single unit, whose perimeter had to be preserved from the illegal entry of persons and goods ${ }^{30}$; yet, in turn, the island was divided into areas of action in order to make the most of the resources available, both human and material, civilian and military. Thus, from the early 1800 s, the island began to be divided into military districts called 'partidas'. By 1818 only four had been established: Llucmajor (southern coast), Artà (eastern coast), Pollença (northern coast) and Andratx (western coast), with one commander and his troops in charge of each one. On 16 August 1821, because of the threat of yellow fever from Barcelona, three cantons were set up, divided in turn into eight districts, each with their respective military company.

The outer cordon, which was established in 1833, was based on the division of the island into four parts, corresponding to the four coastal axes (fronts) that make up its geography, and these were divided into thirteen different maritime districts. Each of the four island fronts was under a high-ranking officer and each district was under another officer with the rank of captain or above, along with three subordinate officers. A maritime cordon was also established. It is worth noting that, in both cases, it was the Captain General of the Balearic Islands, Juan Antonio Monet, who also held the post of president of the superior board of health, who gave the order to set up the cordons on 26 September $1833 .{ }^{31}$

In $1854^{32}$ practically the same land division was maintained as in 1833 , although the fronts were now called districts and the former districts, cantons, and, instead of thirteen, there were twelve; they were also under the charge of military officers whose duty it was to cover their corresponding sanitary division daily. To fulfil their main mission,

to prevent any disembarkation of goods or persons along the coast, the heads of districts and commanders of cantons shall devote all their efforts to keep the most excellent [watch] in all positions. ${ }^{33}$

Different surveillance points were placed in each canton, which in turn could be grouped in blocks, as happened in Palma. It is important to point out that the municipalities in each canton were supposed to co-operate with the army, as explained in the following section.

On 15 August 1885, the Captain General of the Balearics communicated to the delegation that two days later five infantry companies belonging to the Philippines Regiment would leave the capital, 'to station themselves on the points of the island'

\footnotetext{
${ }^{30}$ Logically the setting up of cordons sanitaires is a reaction by the authorities to the ordinary inability to prevent the entry and exit of goods and persons from a territory outside their jurisdiction; that is, contraband. To a certain extent, the cordons make up for the ordinary inability to enforce the law with extraordinary measures. Following these criteria, Peter Baldwin, 'Beyond Weak and Strong: Rethinking the State in Comparative Policy History', The Journal of Policy History, 17-1 (2005), 12-33, considers that certain states, such as Great Britain, had much less need for extraordinary measures of quarantine because the law was much more internalised and adhered to than in other states such as Prussia.

31 Their regulation was published on the same date, 26 September 1833, in a leaflet entitled Disposiciones sanitarias y de higiene pública que deben observarse en estas Islas con motivo de la proximidad del cólera - morbo [Sanitary and public hygiene provisions that must be observed in these islands due to the proximity of cholera] (Palma: Impreso por Felipe Guasp, impresor real, 1833).

32 The first record of the existence of a coastal cordon sanitaire in the municipal records of the capital is not found until the middle of August, whereas their effective withdrawal was from 22 December 1854.

33 '. . . evitar todo desembarco de efectos, ni de personas en la costa, los gefes de los distritos y comandantes de cantones dedicarán todo su conato á que se guarde la más esquisita [sic] en todos los puestos'. From article 6 of the 'Instrucciones á los gefes de distrito y comandantes de cantones, que forman el cordón sanitario del litoral de esta isla' (1854), quoted by Pujadas-Mora, op. cit. (note 16).
} 
namely Andratx (western coast), Sóller (north-east coast), Artà (eastern coast), Pollença (northern coast) and Santanyí (southern coast). ${ }^{34}$ Hence, the compartmentalisation of the space to conform to military requirements was constant throughout the whole period. It is worth noting that this military division of the island did not correspond to any other preexisting division of a civil nature. Majorca was not considered an administrative subject, as it belonged to the province of the Balearic Islands, at the head of which was the civil governor. Meanwhile, the town councils, even the city council in the capital, had no authority beyond their municipal territory. Therefore, the militarised territory of the cordons sanitaires appears as a new space created because of a threat, a theoretically exceptional one, but one which repeatedly transformed the existing political, institutional and administrative reality.

Not only were the cordons directed and co-ordinated by the military establishment, who were able to transform the territory at their convenience, but throughout the 1800s the enterprise became increasingly monopolised by the army to the detriment of civilian personnel and municipal participation, through a process that we can also call professionalisation. In the first cases analysed in Majorca, the model that can be observed must be considered mixed, typical of the eighteenth century; that is, there is co-participation between civilian and military personnel, although always directed by the latter. Thus, in 1794, the cordons had to be carried out according to the authorities,

namely in the outer ring six coastguard boats manned by five sailors, one skipper with a health corporal and a sergeant from the garrison troops and in the inner ring double the guards and tower keepers and the practice of sea rounds under the responsibility of the boroughs. ${ }^{35}$

Therefore, the land cordon was de facto under the responsibility of the town councils and of the civilians in charge.

The primacy of the civilian sector in the first cordons of the century, despite military tutelage, can be evidenced in the cordon of 1800 , when it is pointed out

that to cordon off Palma we shall proceed according to the model initiated during the plague of Marseilles in 1720. That is, based on civilian personnel but with troops at the ready: making sure to have some practical people among them, on the respective coasts. ${ }^{36}$

Only a few years later, in 1813 and 1817, the employment of ground troops already seems to be totally clear; at this time retired military officers were ordered to visit the towers and secret guards ${ }^{37}$ even though at this date the civilian districts organised by the municipalities throughout Majorca persisted. ${ }^{38}$ The presence of soldiers in the land cordons is no longer subsidiary, although they are still a minority with respect to civilians.

A much more spectacular change took place during the liberal triennium (1820-1823), a period in which Majorca was affected by an epidemic of the plague in the region of the Levante or the east coast (Son Servera, Capdepera and Artà) in 1820, and by a yellow fever epidemic in Palma in 1821. In the former, the land army not only made up part of the two

${ }^{34}$ Consell de Mallorca General Archive (AGCM), Establishment of the Sanitary Cordon S-III-262/2.

35 ‘. . a a saber en lo exterior seis barcas guardacostas y tripuladas con cinco Marineros un Patrón con cavo de Sanidad y un Sargento de la tropa de Guarnición y en lo interior la duplicación de guardas y torreros y la práctica de Rondas marítimas al cargo de las villas', Pollença Municipal Archive (AMP), Health-Orders: 2899: 20-61794.

36 'que para el acordonamiento de Palma se procederá según el modelo iniciado durante la peste de Marsella de 1720. Es decir, en base al personal civil, pero con la tropa preparada: procurando poner en ellas alguna gente practica $[\mathrm{sic}]$ en las respectivas costas'. AMP, Health-Orders: 2899.

37 AMP, Health-Orders 2899: 27-8-1817.

38 AMP, Health-Orders 2899. 
cordons sanitaires established (the outer one that covered the whole of the coast and the inner one that isolated the affected area), but the number of their troops was greater than ever. A troop of a thousand men came to be used just for the inner cordon, a number clearly superior to the four hundred infantry civilians and the forty odd cavalrymen who were also used. ${ }^{39}$ Besides, artillery was placed on the perimeter of the area and help was requested of the General Captaincy of Catalonia, in order to increase the military presence. ${ }^{40}$

If we move on from the purely quantitative to the qualitative aspect, it also becomes apparent that militarisation not only involved a greater presence of soldiers, but also that health care itself was increasingly understood in terms of military districts. The documentation of the time clearly reveals a discourse in which the state of war produced by the plague epidemic is made clear. This is a real battle that must be won at all costs. ${ }^{41}$ Most important is the fact that this was not a transitory situation, but rather a repeated threat, resulting from the arrival of cholera in Europe, which reproduced in successive years coercive measures for preventing the illegal entry of goods and persons. Furthermore, a whole series of measures was introduced that affected citizens' way of life. For instance, in 1854 the civil governor made known to the mayors that:

Whoever infringes the maritime cordon sanitaire already set up, or the land cordon that has been ordered to be set up today, not being forced to do so by storms at sea which oblige them to enter ports, inlets or coves, but without jumping over this onto land or breaking the land cordon, shall be considered a malicious threat to public health, be apprehended and punished with extraordinary prison sentences, and even death should disease-carrying items of any sort be introduced. ${ }^{42}$

\footnotetext{
39 Joana Sureda Trujillo, La pesta de 1820 a Son Servera, Artà i Capdepera [The plague of 1820 in Son Servera, Artà and Capdepera] (Palma de Mallorca: El Tall, 1993).

${ }^{40}$ AMP, Health-Orders 1681.

41 Specifically on 28 June 1820, and 'In view of the horrifying results of the contagion of Son Servera and Artà it was declared: Whoever breaks the cordon, or tries to do so, shall be shot on the spot. If they were to escape and the events were proved, they shall be condemned to death within 24 hours. All those who have left Son Servera, Artà, Sant Llorenç or Capdepera after 19 May and have not presented themselves to the justices without justification shall be condemned to death. If any of the guards or watchmen, out of negligence, allow anyone to pass, they shall also be condemned to death. The cordon troop is at war and is up against an enemy. It must be held, as has been stated with the full force of the law, that the troops and other persons employed in the cordon of any sort who are in the campaign, at war and facing the enemy, it is hereby declared, that they are all subject to the penal laws provided for these cases in the general orders of the Army...' ('En vista de los horrorosos estragos del contagio de Son Servera y Artà se declaraba: El que rompa el cordón, o lo intente, será fusilado en el acto. Si consigue escapar y se prueban los hechos, será condenado a muerte en 24 horas. Todos los que hayan salido de Son Servera, Artà, Sant Llorenç y Capdepera después del 19 de mayo y no se hayan presentado a las justicias sin justificación serán condenados a muerte. Si algunos de los guardias o vigilantes, por negligencia, dejan pasar a alguien, también serán condenados a muerte. La tropa del cordón está en pie de guerra y enfrenta a un enemigo. Debiéndose reputar como se ha dicho con todo el rigor de la ley, que las tropas y demás personas empleadas en el cordón de cualquier clase que sean están en servicio de campaña, en función de guerra y al frente del enemigo, se declara, que todos están sujetos a leyes penales prevenidas para estos casos en las ordenanzas generales del Ejército...'), AMP, Health-Orders 1681.

42 ('Todo el que infringiere el cordón sanitario marítimo ya establecido, ó el terrestre que desde hoy se manda establecer, no siendo obligado por razón de tempestades en el mar que lo fuercen á entrar en puertos, ensenadas ó calas, pero sin saltar por esto en tierra ó romper el cordón terrestre, será considerado como atentador malicioso contra la salud pública, aprhendido [sic] y castigado con penas extraordinarias de presidio, y hasta con la muerte si introdujese artículos contumaces de cualquier clase que sean.') 'Likewise, in the same order, meetings in village squares were also banned, especially at night, even those of a festive nature; people were obliged to clean the streets and squares, water tanks, as well as all public and private establishments; and pig, sheep and goat breeding was also banned in the towns, while all manure storage pits had to disappear; lastly, the councils had to appoint sanitary commissions authorised to watch over public health and to carry out visits to private homes and public establishments', Llubí Municipal Archive (AML1), Correspondence-26, 5-8-1854.
} 
During these years, the participation of civilians still remained very high, as shown by the fact that in 1821 a watch of four civilians was appointed to each coastal defence tower, one of whom had to perform the functions of commander; curiously, these were to be preferably churchmen or 'wealthy' people. ${ }^{43}$ Moreover, it would seem that the civilians at that time were paid a wage for taking part in the cordons, which, according to the information available, did not happen prior to 1817 , when participation was similar to a conscription. This fact did not exclude the use of unpaid civilians at exceptional times. In fact, in 1820 the mayors were ordered to send wealthy civilians who could support themselves without pay to the cordon of Son Servera (eastern coast). ${ }^{44}$ Neither did this mean that from that time onwards the districts under the responsibility of the municipalities disappeared. Thus, in 1822 an order was issued that the troop patrols had to interact with those made up of civilians organised by the local boards of health, ${ }^{45}$ even though their days were numbered.

From this last year onwards, the presence of the army was even more decisive in setting up the cordons. The disappearance of the 'sea rounds run by the boroughs' and their replacement by soldiers was the most outstanding fact, as happened in the cordon of 1828. Even so the aforementioned patrols were reinforced with armed civilians, directly integrated into the army's chain of command. ${ }^{46}$ There is therefore, an increase in the military nature of the quarantine measures, but without the complete disappearance of civilian personnel therein.

As the century advances, the role of civilians becomes a subsidiary force or reinforcement for cordons that are basically military in both nature and practice. Civilians were used only as a response to the insufficient number of soldiers garrisoned on the island. We see this in 1834, when the defensive ring was initiated exclusively with soldiers, and it was not until the month of November that seventy-eight civilians were incorporated in order to reinforce the coast, from Felanitx (south-eastern coast) to Pollença (northern coast). ${ }^{47}$ In fact, from the date of the arrival of cholera, the quarantine lines were above all almost exclusively military, even though at the time the mobilisation of part of the civilian population was necessary. This was due to the limited number of soldiers garrisoned on Majorca and/or to the warfare needs of the time, always allowing for the precariousness of the finances of the Spanish state. Furthermore, the incorporation of civilians would also take on a much more professional aspect than in the immediate past, as it was not a compulsory, unpaid service similar to that at the turn of the century, but rather voluntary and paid.

\footnotetext{
43 AMP, Health-Orders 1681.

44 AMP, Health-Orders 1681: 5-6-1820.

45 AMP, Health-Orders 1681: 01-6-1822.

${ }^{46}$ For instance, the military government of Alcúdia said to the mayor of this town that 'According to the Health Board, with soldiers under my command and with civilians, a cordon sanitaire on the coast of the district of this town has been established and all the points where landings could be made, considering the nature of the land, have been taken ... the same has been verified in the cordon in Pollença, according to an official notice which with twenty men I sent to said borough. ...' From the original quotation, 'De acuerdo con la Junta de Sanidad con soldados de los de mi mando y con paysanos, queda establecido un Cordón de Sanidad en la Costa marítima del distrito de esta ciudad y tomados todos los puntos que vista la naturaleza del terreno se pueden hacer desembarcos en ellos. . . lo mismo se ha verificado en la de Pollensa, según un aviso de un oficial que con veinte hombres mandé a dicha villa. ...' (Archive of the Kingdom of Majorca (ARM), Provincial Board of Health (JPS) Correspondence 95: 30-9-1828).

${ }^{47}$ AMP, Health-Orders 1681: 11-11-1834.
} 
The initial cordon sanitaire created in 1849 was composed of military personnel. Civilians began to be incorporated temporarily from 8 December, because some of the troops were required to be sent to the mainland. In fact, on the 14th of the same month, civilians were once again relieved by soldiers, ${ }^{48}$ proof of the exceptional nature of their presence. During the cholera outbreak in 1865 , the cordon was completely militarised, with the exclusive participation of 'army forces, tower keepers, coastguards, border guards and Guardia Civil' ${ }^{49}$ That is, at this time there were also members of the recently created police forces involved, such as the Guardia Civil, and, of course, the border guards, making up in part for the tower keeper corps that had been closed down in 1866. Be that as it may, the following year we once again find civilians hired by the municipalities to perform surveillance tasks at certain points along the coast ${ }^{50}$ and all the indications are that in 1867 their participation was even greater. In this situation, intense, repeated protests by the population break out in many towns due to the difficulties created by the use of their residents in surveillance tasks. ${ }^{51}$ This reflected their opposition to their participation as it was considered obsolete, ineffective and damaging to the community, in which residents had become citizens with recognised rights.

This model, which began in 1828 and must be considered military in nature, reinforced with militarised civilians, would be maintained practically until the beginning of the $1880 \mathrm{~s}$. After and including 1884, there are no further references to the presence of civilians in the cordons sanitaires set up on Majorca. It could be thought, therefore, that from this time onwards militarisation had been completed. It marks the end of a progressive tendency towards the participation of the army in extraordinary health care, initiated at the beginning of our period. We do not believe it is possible to separate this from the development of the central state in Spain and its delegated institutions, which is typical of the European context in the second half of the nineteenth century. ${ }^{52}$ In turn, it also illustrates the rise in functional specialisation, social complexity and interdependencies among members of society. ${ }^{53}$

\section{The Persistence of Municipal Participation}

Paradoxically, the progressive centralisation and rationalisation of the cordons sanitaires did not eliminate the participation of the municipal and provincial administration. What is more, although their importance was on the wane, both town councils and the delegation continued to be essential to ensure their effectiveness.

\footnotetext{
48 AML1, Correspondence 25.

49 AGCM, Establishment of Cordon sanitarie S III 249/33.

50 AGCM, Establishment of Cordon sanitarie S III 249/33.

51 AGCM, Establishment of Cordon sanitarie S III 249/37.

52 At this point, emphasis should be placed on the 'bureaucratisation' of the public health administration during the first liberal-fusionist governments of the Restoration, the case of the Royal Decree of 1886 whereby the marine health authority was created (Jorge Molero Mesa and Isabel Jiménez Lucena, 'Salud y burocracia en España: Los cuerpos de sanidad nacional (1855-1951)' [Health and bureaucracy in Spain: the national health authorities], Revista Española de Salud Pública, 74-007 (2000), 45-53) and the creation of the provincial inspectors, and also of family doctors in the municipal field. See Carmen Barona Vilar, 'Organización y profesionalización de la asistencia médica domiciliaria en los pueblos de la provincia de València: 1854-1936' [Organisation and professionalisation of home health care in the towns in the province of Valencia], in J.L. Barona Vilar (ed.), Polítiques de salut en l'àmbit municipal valencià (1850-1936) (València: Seminari d'Estudis Sobre la Ciència, 2000), 13-70.

${ }^{53}$ Norbert Elias, El proceso de la civilización: Investigaciones sociogenéticas y psicogenéticas [The process of civilisation: sociogenetic and psychogenetic research studies] (Madrid: Fondo de Cultura Económica, 1987).
} 
Firstly, it is worth remembering that in the first decades of the century, coastal municipalities were in charge of organising the land rounds in the cordons. Both their members and their maintenance on the ground were wholly supplied by all of the boroughs on the island. ${ }^{54}$ The municipality also constituted the mechanism necessary to connect the higher authorities with the population. This remained as an essential aspect in order to put orders into practice. ${ }^{55}$ During the plague of 1820 , the town councils became highly involved in the various cordons, but under the direct orders of the higher authorities, whether military or civilian. The mayors had to place the resources of their respective municipalities at the service of quarantine measures, thereby helping to supply the men and material that the outer and inner cordons required.

Nevertheless, even after the disappearance of the civilian rounds and their replacement by the army, the municipalities continued to perform two primordial functions: firstly, they supplied the personnel that the troops lacked until 1884; and secondly, they took charge of their food and lodging needs, as well as making a special payment called a 'bonus' ${ }^{56}$ In short, it can be said that the cost of the cordons was defrayed by the town councils, upon which all the extraordinary expenditure claimed by the military or the civilians themselves fell, whenever they were required. They also had to pay for the costs to the state, for the use of the army. The reason for this formula lies in the fact that the cordons were considered an issue exclusive to Majorca and, as a result, could not be defrayed by the provincial institutions with jurisdiction throughout the archipelago (Balearic Islands); neither could they be covered by the ministry of war alone because it did not have the funds to take on extraordinary expenses, since the activity in question was not qualified as strictly military. ${ }^{57}$

Not surprisingly, problems relating to financing and organisation appeared. The former emerged as soon as the municipalities on the coast were required to supply funds needed to establish the cordon, as there was no type of budget envisaged in any institution in the province for this purpose. This fact sparked off real problems in the early years. Hence, at certain points along the coast during the cordon of 1828, the soldiers' situation was deplorable due to the neglect they suffered at the hands of the local authorities. ${ }^{58}$ Only after the coastal municipalities were guaranteed repayment, through a general sharing out with all the municipalities in the island, of the money and the material advanced to the soldiers did surveillance return to normal. ${ }^{59}$ This model of action was to be reproduced until the end of the century. The degree of acceptance was fairly widespread, and problems

\footnotetext{
${ }^{54}$ AMP, Health-Orders 2899, 20-6-1794. On this topic, the defensive model introduced during the ancien régime on Majorca in response to the corsair threat was followed. See Miquel Deyà, Antoni Mas and Ramon Rosselló, Història d'Alcúdia: El segle XVI (Alcúdia: Ajuntament d'Alcúdia, 1999) [History of Alcudia: the 16th century]. 55 See Concepción de Castro, La Revolución Liberal y los municipios españoles (1812-1868) [The liberal revolution and Spanish municipalities] (Madrid: Alianza, 1979), and Pedro Carasa Soto (ed.), Ayuntamiento, Estado y Sociedad: Los poderes municipales en la España contemporánea [Council, state and society: municipal powers in contemporary Spain] (Valladolid: Fundación Municipal de Cultura - Instituto de Historia "Simancas", 2000).

56 AGCM, Establishment of Cordons sanitaire S III 262/1: 24-9-1884.

57 AMLl, Correspondence 29, 18-8-1885.

58 Proof of this assertion were the difficulties of all sorts experienced by the troops stationed in Santa Margalida in 1828 (ARM, JPS Correspondence 95: 30-09-1828).

${ }^{59}$ Likewise, the municipalities had to concern themselves with building barracks and providing wood for the soldiers, while avoiding harming private interests, and with providing the corresponding receipts, proof that they were recoverable amounts (AMP, Health-Orders 1681, 24-10-1834).
} 
with the troops mostly disappeared in practice. However, this did not mean there was no longer any tension between inland and coastal town councils.

In fact, the difficulties with municipal finances worsened as the century advanced. This was mostly due to the large number of functions, other than health, that had to be carried out at the expense of the central government. There is no doubt that this situation left the local authorities with little leeway to cope with extraordinary obligations, above all if these, in practice, became almost commonplace, as in the case of the quarantine policy. Hence, it is not surprising that payment of the respective distribution shares was nearly always overdue, thereby further exacerbating the position of the municipalities that had advanced the payments. ${ }^{60}$ Besides, from the moment when civilian participation in the surveillance tasks became subsidiary to the troops, and in the absence of general regulations, it was normally the residents of the coastal towns who completed the cordon. In 1854, because of the complaints about this situation which was considered unfair, such as the one lodged by Manacor town council (a coastal municipality in the east of Majorca) in September 1854, the governor of the province published a memo on 22 October of that year establishing the number of residents that should be provided by inland towns and the surveillance point on the coast where they were to settle. Even so, after the total withdrawal of the troops on 15 November, only residents from Manacor took charge of the cordon without receiving any help from the inland towns. ${ }^{61}$

The unsatisfactory operation of this system led in 1865 to the introduction of advance sharing out of the possible costs of setting up a cordon. This idea failed due to the legal incapacity of the provincial government to make the town councils enforce expenditures that did not figure in their budgets. This situation also highlighted the limitations of institutions to deal with financing actions which, paradoxically, were considered vital for health maintenance. The situation cannot have been very clear when in 1890, at the request of several councils, the provincial commission of the delegation had to point out that

The forces that are providing the service of the cordon sanitaire must be paid in cash from the Custodian of Provincial Funds the bonus which for this purpose has been assigned to them, and, therefore, even though the Council, in compliance with what is provided in the article of the instruction dated 9 August 1877, is obliged to provide them with the livelihood and utensils they need, the value of all the goods supplied must be reimbursed by the Military Administration in the form provided for in the aforementioned instruction. ${ }^{62}$

However, despite the lack of solidarity that tended to reign among the inland and coastal boroughs, the problems did not become so serious as to prevent the establishment of any cordon nor to undermine their effectiveness.

In addition, in spite of the extraordinary expense the army caused to local revenue offices, its participation was increasingly requested by the municipal administrations

${ }^{60}$ AML1, Municipal Records: 29-01-1850; Montuïri Municipal Archive (AMMo), Municipal Records: 07-21850; Alcúdia Municipal Archive (AMA), Municipal Records: 24-5-1874; AMLl, Municipal Records: 02-81874; Capdepera Municipal Archive (AMC), Municipal Records: 29-7-1865; AMMo, Municipal Records: 124-1892 or, among others, AML1, Municipal Records: 14-03-1894. Curiously, in January 1888 the Council of Andratx (western coast) refused to pay the prison expenses in their judicial district, until they had been reimbursed the advances made to pay for the cordon sanitaire two years previously (AMA, Municipal Records: 15-1-1888). ${ }^{61}$ Manacor Municipal Archive (AMM), Municipal Records: 22-9-1854, 19-10-1854 y 12-11-1854.

62 'Las fuerzas que están prestando el servicio del cordón sanitario deben percibir en metálico de la Depositaria de la Fondos provinciales el plus que con este motivo les ha sido señalado, y por lo tanto si bien los Ayuntamiento en cumplimento de lo dispuesto en el art $^{\circ}$ de la instrucción de 9 de Agosto 1877 vienen obligados á subministrarles las subsistencias y utensilios que necesiten el valor de todas las especies que subministren deberá serles reintegrado por la Administración Militar en la forma que previene la citada instrucción.' (AGCM, Establishment of Sanitary Cordon S-III-246/31, 9-9-1890). 
themselves. It was not from the direct intervention of the citizens. Perhaps this was because they were supposed to earn a wage which, in the end, also covered corporation taxes, while the normal development of economic activity was reduced to a large extent. Yet, above all, the use of volunteers was avoided and progress was made in the militarisation of the quarantine measures. In fact, in the cordons sanitaires following 1884, no council raised its voice against the payment in cash of the quotas aimed at financing an exclusively army service nor against the way of sharing this out among municipalities.

\section{Consensus and Demands for Cordons Sanitaires}

Throughout the period studied an important consensus evolved in favour of the cordons run on behalf of the provincial and local authorities, the population at large, and the medical authorities, with some exceptions in 1865 as we shall see immediately below. Initially, we might expect the opposite, as, in order to become accepted ${ }^{63}$, preventive medicine, unlike curative medicine, has traditionally required a high degree of coercion ${ }^{64}$ or demand and mobilisation by specific sectors of the population. The reasons why this did not happen on Majorca are certainly diverse. One of them could be its inclusion in a long tradition dating back to the Middle Ages, ${ }^{65}$ with the result of adopting isolation as a normal action in the face of an epidemic threat. ${ }^{66}$ Nor were there significant discrepancies within the medical establishment concerning the adoption of this type of measure, but rather a predominance of a sort of eclecticism between contagionism and hygienism when it came down to proposing anti-epidemic measures. ${ }^{67}$ Only from the start of the twentieth century did medical science and public health shelve coastal cordons sanitaires, when they were replaced by other kinds of protective measures.

Proof of this consensus is provided by the behaviour of the town councils over the period studied. Not only did they participate in the organisation and funding of the cordons

${ }^{63}$ In Great Britain and in the United States, for instance, the population was much more in favour of contagionism and, therefore, of cordons sanitaires than the public and medical authorities. See George Davey Smith, 'Commentary: Behind the Broad Street pump: Aetiology, Epidemiology and Prevention of Cholera in Mid-Nineteenth-Century Britain', International Journal of Epidemiology, 31 (2002), 920-32.

${ }^{64}$ Vicente Pérez Moreda, Las crisis de mortalidad en la España Interior (siglos XVI-XIX) [The mortality crises in inland Spain (16th-19th centuries)] (Madrid: Siglo XXI, 1980), 418.

65 In 1867, for instance, the provincial government justified the establishment of the cordon sanitaire 'which is so deeply rooted in this island and which public opinion calls for in similar circumstances as one of the most efficient models', as well as other considerations ('en la que se halla tan arraigada en esta isla y que la opinión pública reclama en semejantes circunstancias como uno de los medios más eficaces') (AGCM, Establishment of cordon sanitaire S-III-249/33: 13-8-1867).

66 Obviously, this is not a characteristic exclusive to Majorca. As noted by Carlo M. Cipolla, Contra un enemigo mortal e invisible [Against a mortal, invisible enemy] (Barcelona: Crítica, 1993): 93, and Eugenia Tognotti, op. cit. (note 2), 254-59, the isolation system had a long tradition in southern Europe and, specifically, in northern Italy and on the Italian islands.

${ }^{67}$ Not all countries acted in the same way, as demonstrated in the successive international sanitary conferences from 1851 onwards. See Valeska Huber, 'The Unification of the Globe by Disease? The International Sanitary Conferences on Cholera, 1851-1894', The Historical Journal, 49, 2 (2006), 453-476, and Josep Lluis Barona Vilar and Josep Bernabeu-Mestre, La salud y el Estado: El movimiento sanitario internacional y la administración española (1851-1945) [Health and the state: the international health movement and the Spanish administration] (Valencia: University of Valencia, 2008). It is true, however, that eclecticism was not an isolated case in Majorca but rather much more widespread than had been thought to date (Christopher Hamlin, 'Commentary: Ackerknecht and 'Anticontagionism': A Tale of Two dichotomies', International Journal of Epidemiology, 38 (2009), 22-27). At the same time, it is important to note that 'Indeed quarantine and customs border policing, and the cordon sanitaire, were crucial places and practices for the emerging political reality of sovereign territory', as it is argued by Alison Bashford, 'Global Biopolitics and the History of World Health', History of the Human Sciences, 19-1 (2006), 67-88, 70. 
sanitaires as we have seen, but they also demanded their establishment and even cordoned off their own towns on the five occasions $\left(1820,1821,1854,1865\right.$ and 1870) ${ }^{68}$ that an epidemic had affected some part of the island. It is worth noting that, as of 1855, these measures were blatantly illegal, contrary to before this date, when the councils were even exhorted by the higher authorities to proceed with their own cordons. Indeed, this is exactly what happened during the plague of 1820, a time when the local authorities responded to this call with great zeal. Yet perhaps the most extreme situation was experienced in September 1821. In order to concentrate on the isolation of the city of Palma, the superior board of health withdrew troops from their respective districts. Once yellow fever had been declared in the capital in 1870, this forced the municipalities to defend themselves with their own forces, both in the outer and inner rings. ${ }^{69}$ What is more, on 30 October, 1,660 men were summoned from the 'Part Forana' (Rest of Majorca beyond Palma) ${ }^{70}$ to reinforce the cordon in Palma. ${ }^{71}$

From now on, the town councils did not hesitate to demand quarantine measures whenever another epidemic threatened to arrive in the island. Nor were they reluctant when it came to collaborating with their own measures, as we have already seen. This predisposition may also have been due to their own experience learnt from the two aforementioned epidemics in 1820 and 1821. There is no doubt that the arrival of the plague in the eastern region - the most terrible and feared of the epidemics - and, to a lesser extent, the yellow fever in Palma in 1921, acted as a wake-up call for the provincial, local, and even central authorities as well as among the population at large. The death of almost two thousand people alone in the summer of 1820 confirmed the worst fears of the sanitary and political authorities, ${ }^{72}$ even while they were justifying the loss of freedom, justifying the disciplinary measures and justifying their high economic cost. They held to this position even in the face of the strengthening thesis of those in favour of contagionism, beyond any ideological belief. Besides, it is worth recalling that, in the above cases, the epidemic was declared on the island before the establishment of the outer cordon. Once the quarantine measures had been imposed, they managed to contain the epidemic within the initial focal points. Therefore, both cases highlighted the potential danger of the epidemic threat at a time of progress and predisposed society at large to be favourably inclined towards prophylactic and coercive measures, in addition to stimulating the increase in public hygiene.

It is not surprising that, from now on, as well as demanding the establishment of cordons, the town councils themselves did not hesitate to supplement personnel from their own resources whenever the army contribution was insufficient. For instance in 1849, due to the demobilisation decreed by the central government, the civil governor had no problem with the municipalities substituting civilians for soldiers that to that date had made up part of the cordon. What is more, the mayors were urged:

\footnotetext{
68 Or, similarly, during the episodes of the plague in Son Servera (1820), yellow fever in Palma (1821), cholera in Andratx and Palma (1854 and 1865 respectively) and yellow fever in Palma in 1870.

69 AMP, Health-Orders 1681 (1820-1835/1870), 13-9-1821. The municipalities did not need the order to proceed to isolate themselves to be repeated as they had done so a few months previously due to the plague in 1820 .

70 Traditionally the island of Majorca has been divided between the capital (the city of Palma) and the rest of the towns located outside the city walls.

71 AMP, Health-Orders-1681 (1820-1835/1870): 3-10-1821.

72 In the town of Son Servera the death rate was of the order of 650 per thousand (Jaume Alzina Mestre, Població, terra i propietat a la Comarca de Llevant de Mallorca (Segles XVII/XIX-XX) [Population, land and property in the eastern region of Majorca (17th-20th centuries)] (Artà: Ajuntament d'Artà, 1993)).
} 
you will seek to achieve the best harmony between the civilian posts and the ones occupied by the troops by helping each other mutually and passing on notice of any new development to the military command who, being more experienced in this sort of service, are able to proceed with greater success in any unexpected event. ${ }^{73}$

In 1866 , at a meeting called by the provincial commission itself, attended by the mayors and local elite in order to find out 'the opinion and will of the country with respect to the surveillance cordon measure on the coasts of Majorca', it was unanimously agreed that 'there would be a cordon', and that it would be made up 'of the army forces, tower keepers, coastguards, border guards and Guardia Civil' ${ }^{74}$ Decades later, the councils again spoke out in favour of the cordons sanitaires, even when they had to take on the extra numbers demanded by the army, as we have already seen. In addition, some town councils, such as Sant Joan (in the centre of the island), reported through official channels 'that it sees with great pleasure the measures that are being taken to free from contagion. . ' 75

However, perhaps the clearest stance on behalf of the population of Majorca in favour of the cordons sanitaires was produced as a result of the declaration of cholera in 1865 and yellow fever in 1870 in Palma. In the first case, the new governor, Adolfo García de León y Pizarro, who had arrived on the island on 27 August 1865, issued almost immediately a series of clearly anti-contagionist measures to curb the spread of cholera on the island. These included the reduction of the number of soldiers devoted to the outer cordon, preventing the isolation of Palma when several cases of cholera had already been declared. Following the law of 1855, he reiterated the prohibition of self-isolation to the boroughs, even though most of them set this in motion. In fact, they were doing nothing less than following the identical pattern of behaviour in the previous cases of epidemics on Majorca. The response of the mayors in the rest of Majorca outside Palma was blunt: they refused to obey and kept up their cordons. This led to an initial, certainly interesting, memo from the governor in the following terms:

Therefore, being unable to believe that the intention of the local authorities who are involved in the aforementioned case was to rebel against the law, given the proverbial loyalty of the Balearic people, but rather that they will have obeyed their natural instinct in view of the unjustified alarm caused by the part of this community which has fled, I expect the mayors to whom I am referring, in view of the aforementioned legal precept and being better informed of the state of health of this city, to immediately take down the cordon sanitaire, on the understanding that if this were not verified I will be obliged to adopt rulings that I wish to avoid. $^{76}$

Despite its forcefulness, we have evidence that the order had little effect. The evidence clearly shows that in Inca (in the centre of the island), Establiments (north of the city of Palma), Sóller (north-western coast), Alaró (centre of the island) and Alcúdia

\footnotetext{
73 'procurarán que reine la mejor armonia entre los puestos de paisanos y los que ocupe la tropa ausiliándose mutuamente y pasando aviso de cualquiera novedad á los gefes militares que mas esperimentados en esta clase de servicio se hallen en el caso de proceder con mayor acierto en cualquier ocurrencia', AMLl, Correspondence25, 4-12-1849.

${ }^{74}$ AGCM, Establishment of Cordon Sanitaire S-III-249/33: 28-8-1866.

75 AMC, Municipal Records-1285: 28-09-1884 y AGCM, Establishment of Cordon Sanitaire S-III-262/2: 31-81885 .

76 'Por lo tanto y no pudiendo creer que el ánimo de las autoridades locales que se hallan en el caso referido, haya sido la de rebelarse contra la ley, toda vez que es proverbial la lealtad de los baleares, sino que habrán obedecido al natural instinto en vista de la injustificada alarma de la parte de este vecindario que ha huido, espero de los señores Alcaldes á [sic] quienes me refiero, en vista del citado precepto legal y mejor informados del estado sanitario de esta ciudad, levantarán inmediatamente el cordón sanitario, en la inteligencia que de no verificarlo me veré precisado á $[\mathrm{sic}]$ adoptar disposiciones que deseo evitar'. Memo from the government of the province, 29 August 1865 in the official gazette of the province of the Balearic Islands (BOPB) $\mathrm{n}^{\mathrm{o}} .5 .129$ de 30-08-1865. Also of interest is BOPB, $n^{\circ}$. 5.132 de 25-9-1865.
} 
(northern coast) ${ }^{77}$ strict quarantine measures were maintained, while in other municipalities there were disputes with the population when their respective councils decided to comply with the memos from the provincial governor. ${ }^{78}$ To make matters worse, the press, even the more typically progressive press, agreed with the municipalities that rebelled over the re-establishment of the cordons sanitaires. ${ }^{79}$

The clash between the mayors and the governor did not stop until weeks after the epidemic had been eradicated. The press, also, echoed the fact that one of the last memos in this regard dated 25 September, again 'strictly' forbade the mayors and municipal boards of health to impose their cordons sanitaires. This was systematically disobeyed, giving rise to a multitude of incidents. ${ }^{80}$ Finally, it would seem that the highest provincial authority gave in. From that time on, its main concern was only to avoid abuses in the quarantines and not so much their elimination. ${ }^{81}$ Meanwhile, as far as the coast is concerned, the army did not return to its barracks until 22 October 1865, when the danger of the disease entering the island had completely disappeared. ${ }^{82}$

The stance of the town mayors was similar to that of the permanent commission of public health made up ad hoc of individuals from the municipal board and the provincial board of health. This commission expressed its support for setting up a land cordon in the capital. On 18 September news emerged of the commission's agreement regarding the convenience for

Palma and boroughs in Majorca [of] the establishment of a cordon sanitaire around the city, like the one established in 1821 [episode of yellow fever], interpreting the wish of the majority of the inhabitants in the island. ${ }^{83}$

Interestingly, most published opinion held the view 'that this measure, rejected by the Governor, favoured numerous families who could not find food except at very high prices' ${ }^{84}$ Note that the press is totally in favour of the contagionist measures.

Finally, in early 1866 the governor relinquished his duties and his replacement, Primitivo Seriñá, had obviously learnt the lesson, as did his successors. They gave up on their anti-quarantine stances. In fact, during the episode of yellow fever in Palma in 1870 , the boroughs went back to quarantining themselves with no record of any sort of backlash from the civil governor. ${ }^{85}$

77 J. de Oleza y de España, 'Episodio en la vida de un pueblo: El cólera de 1865 en Palma: La Gente balear durante la epidemia: Lazareto, cuarentenas, cordones sanitarios y disposiciones legales' [Episode in the life of a people: cholera in 1865 in Palma: the Balearic people during the epidemic. . . ], Boletín Estadística Municipal de Palma, 1966, 59, 5-9, 5.

${ }^{78}$ In fact, in Sineu (in the centre of the island) for instance, popular protest triggered an extraordinary meeting of the town council, municipal board and leading taxpayers to decide whether the cordon was to be raised once again, the resolution of which remains unknown (Sineu Municipal Archive (AMS) Municipal Records: 1-9-1865). Even more spectacular is the case of Alcúdia (northern coast), where the cordon is imposed on 3 November, just after the aforementioned memo from the governor is received (AMA, Municipal Records: 3-91865).

${ }^{79}$ El Isleño, 12-9-1865 and Juan Llabrés Bernal, Noticias y relaciones históricas de Mallorca: Siglo XIX [News and historical relations in Majorca: 19th century] (Palamós: Alcover, 1966), 313.

${ }^{80}$ Ibid., 317.

81 BOP-5132 de 25-9-1865.

82 AMA, Municipal Records: 22-10-1865.

83 'Palma y villas de Mallorca el establecimiento de un cordón sanitario en los alrededores de la ciudad, como el establecido en 1821 (episodio de fiebre amarilla), interpretando el deseo de la mayoría de los habitantes de la isla', Llabrés Bernal, Noticias y relaciones históricas de Mallorca, 315.

84 Ibid., 316.

${ }^{85}$ For instance, Alaró maintained the cordon sanitaire from 10 October to 22 November 1870 (Alaró Municipal Archive (AMAl), Municipal Records: 10-10-1870 and 22-11-1870). Meanwhile, Alcúdia made all new arrivals observe five days of quarantine and three days for their goods (AMA, Municipal Records: 30-10-1870). 


\section{Conclusions}

As has already been seen, it is paradoxical that the most radical and extraordinary form of health protection, the cordons sanitaires, ceased to be an occasional practice during the nineteenth century and became something of a norm, with wide social, medical and political acceptance. In this sense, Majorca was the perfect example in the context of the Mediterranean area. On the one hand, during the first half of the nineteenth century, the application of isolation measures such as quarantines and cordons sanitaires was a common practice, especially in easily delimited maritime enclaves such as islands or peninsulas. Even British colonies like Gibraltar and Malta applied them, as well as Egypt. The situation changed after the first International Sanitary Conference in 1851, when only Tuscany, the kingdom of Naples, the Papal States, Greece and Spain retained their use. From that point on, these measures were softened and rationalised, and the establishment of cordons sanitaires was restricted and placed under the authority of the central government in Spain. In any case, the fact that states carried on controlling their ports and applying rationalised quarantines should not be ignored.

Having said this, it is also true that the case study shows certain peculiarities, especially during the second half of the nineteenth century up to 1890. During this period, epidemic prevention by means of the establishment of cordons sanitaires maintained a consensus on Majorca that perhaps was stronger than in other places, even other places in the Mediterranean. This fact could be due to both external and internal factors. In the first place, even after 1851, experts argued for the effectiveness of cordons sanitaires in preserving small islands or certain peninsulas with a relatively small perimeter to defend. Local history supported this claim, as epidemic threats were kept away from the island and, when they were not, epidemics were contained thanks to the use of cordons sanitaires. ${ }^{86}$ In addition, there was at the time no understanding of the pathological process nor, for that matter, any preventive therapies. It is therefore not surprising that Majorcan physicians supported polices based on miasmatic and contagionist theories.

We need to consider the geographical situation of Majorca as one of the determinants in the extended use of cordons sanitaires. The Balearic Islands are located in a border area between Africa and Europe, on the commercial routes between the regions. In addition, they had good connections with the east and Latin America. All these places were considered potentially dangerous for plague, yellow fever or cholera. Accordingly, the perception of danger in Majorca was permanent and evident, especially when in 1820 and 1821, plague and yellow fever severely affected certain areas of the island. At the time, it was believed that smugglers from North Africa or from Barcelona had imported those diseases. This belief coexisted with the strong presence of plague on the African coast of the Mediterranean and cholera on the European coast. Moreover, this period was characterised by an increase in commercial traffic and blame laid on Islam and the uncivilised East.

We may believe, therefore, that the use of quarantines and preventive measures was vital to ensuring the commercial traffic on which the prosperity of the island and its entry into modernity depended. In the absence of other scientific alternatives, the use of this kind of measure, even one so radical, endorsed by the local, and partly by international, medical authorities, was likely to reduce anxiety among Majorca commercial partners. In this way, although cordons slowed contact it quickly resumed after the danger. For

${ }^{86}$ That was not only true for Majorca. For other territories, see E. Tognotti, op. cit. (note 2). 
this reason, commercial elites could even feel comfortable with the contagionist policy as it actually occurred on Majorca in general. On the other hand, the local and provincial liberal authorities had other reasons for adopting an approach that had the endorsement of the population and of local scientists. These were none other than to ensure social order and the stability of public offices, undermined by any epidemic, as occurred with the outbreak of cholera in Palma in 1865. At this point, we emphasise that the liberal state always prioritised the right to life, and even public order, over individual freedom, a fact that was accepted by a majority of the population, as we have seen. ${ }^{87}$ Only when bacteriology proposed truly effective and credible arguments were the cordons abandoned.

At this point, it is worth highlighting the fact that quarantines and cordons sanitaires not only helped to modernise the island by preserving it from epidemics and thereby maintaining the social order, but were also made possible by the emergence of national, provincial and local administrations that were more capable and effective than Old Regime institutions. That is, without the progressive bureaucratisation-rationalisationmilitarisation of cordons sanitaires during the nineteenth century, they would not have proved effective and would have been rapidly discredited. In other words, this case study is part of the process of state growth that Michael Mann noted for western countries during this time, as we stated earlier.

Finally, we cannot ignore the fact that the cordons sanitaires were successful. There were only five epidemics on Majorca during the nineteenth century, and these affected the island only partially. Moreover, the sharp rises in mortality became more gradual and short-lived during the same period. This is one more reason to support the contention that coercion in the service of preservation of health can attain a high degree of consensus and can also predispose society to accept new demands from the state or from medical science.

\footnotetext{
${ }^{87}$ We need to bear in mind that, in Europe, liberalism was implanted in societies in transition from the Old Regime, as stated by A. Mayer, The Persistence of the Old Regime: Europe to the Great War (New York: Pantheon, 1981). Moreover, the acceptance rather than the imposition of a certain biopolitics, implying acceptance of health discipline by the population, has already been theorised by M. Foucault; see Patrice Bourdelais, op. cit. (note 3), among others.
} 